\title{
PENGARUH PEMBERIAN KOMPOS SEKAM TERHADAP \\ PERTUMBUHAN DAN HASIL TANAMAN TERUNG (Solanum melongena, L.) PADA TANAH PMK
}

\author{
Markus Sinaga \\ Fakultas Pertanian Universitas Kapuas Sintang. \\ Email: markusagronomi@yahoo.co.id
}

\begin{abstract}
Abstrak: Pemberian bahan organic seperti kompos sekam perlu dilakukan dalam mencukupi bahan organik tanah, terutama pada tanah PMK. Penelitian ini bertujuan untuk mengetahui pengaruh pemberian kompos sekam terhadap pertumbuhan dan hasil tanaman terung pada tanah PMK, dan mengetahui dosis pemberian kompos sekam yang memberikan pengaruh terhadap pertumbuhan dan hasil tanaman terung pada tanah PMK. Lingkup penelitian ini terdiri variabel bebas dan variabel terikat. Variabel bebas pada penelitian ini adalah kompos sekam. Variabel terikat meliputi, tinggi tanaman, diameter batang, dan berat buah. Penelitian ini dilakukan dengan metode eksperimen lapangan dan menggunakanrancangan lingkungan dengan pola Rancangan Acak Kelompok (RAK). Faktor perlakuan pada penelitian ini adalah kompos sekam padi yang terdiri dari sembilan taraf perlakuan, yaitu: $\mathrm{k}_{0}=$ tidak diberi kompos sekam; $\mathrm{k}_{1}=0,5 \mathrm{~kg}$ kompos sekam per $\mathrm{m}^{2} ; \mathrm{k}_{2}=1 \mathrm{~kg}$ kompos sekam per $\mathrm{m}^{2} ; \mathrm{k}_{3} \quad=1,5 \mathrm{~kg}$ kompos sekam per $\mathrm{m}^{2} ; \mathrm{k}_{4}=2 \mathrm{~kg}$ kompos sekam per $\mathrm{m}^{2} ; \mathrm{k}_{5}=2,5 \mathrm{~kg}$ kompos sekam per $\mathrm{m}^{2} ; \mathrm{k}_{6}=3 \mathrm{~kg}$ kompos sekam per $\mathrm{m}^{2} ; \mathrm{k}_{7}=3,5 \mathrm{~kg}$ kompos sekam per $\mathrm{m}^{2} ; \mathrm{k}_{8}=4 \mathrm{~kg}$ kompos sekam per $\mathrm{m}^{2}$. Data dianalisa dengan uji F dan uji BNJ. Hasil penelitian diketahui bahwa Pemberian kompos sekam berpengaruh terhadap pertumbuhan dan hasil tanaman terung pada tanah PMK. Pemberian kompos sekam $2 \mathrm{~kg}$ per $\mathrm{m}^{2}$ pada tanah PMK menghasilkan berat buah tertinggi dengan berat rata-rata $0,33 \mathrm{~kg}$ atau 330 gram per tanaman.
\end{abstract}

Kata kunci: Kompos sekam, Pertumbuhan, Hasil, Terung, Tanah PMK

\section{PENDAHULUAN}

Produksi terung di Kabupaten Sintang rata-rata 2,8 ton per hektar danmasih sangat rendah bila dibandingkan dengan produksi Nasional yang mencapai 6 ton per hektar (DEPTAN RI, 2010). Penyebab rendahnya produksi inididugakarena factor kesuburan tanah, karena jenis tanah yang diusahakanoleh petani sebagian besar tanah PMK. Menurut data
Badan PusatStatistik Kabupaten Sintang (2015) luas tanah PMK mencapai 1.214.820 Ha dari luas wilayah Kabupaten Sintang $12857,70 \mathrm{~km}^{2}$. Menurut Hardjowigeno (1992), tanah podsolic merah kuning merupakan tanah dengan penimbunan liat di horizon bawah, bersifat masam, kejenuhan basa pada kedalaman $180 \mathrm{~cm}$ dari permukaan tanah kurang dari $35 \%$, reaksi tanah yang 
masam, kandungan Al yang tinggi dan unsur hara serta bahan organic rendah.

Kondisi tanah sangat mempengaruhi pertumbuhan dan hasil tanaman, karena itu penambahan bahan organic seperti kompos sekam perlu dilakukan agar bahan organik tanah meningkat sehinggahasildan produksi tanaman pertanian juga meningkat tidak terkecuali tanaman terung. Pemberian kompos sekam mampu meningkatkan produtivitas tanah PMK,karena mampu mengikat unsur $\mathrm{Al}$ dan $\mathrm{Fe}$ sehingga unsur hara $\mathrm{P}$ dapat bebasdan terserapolehtanaman.

Penelitian ini bertujuan untuk mengetahui : (1) Pengaruh pemberian kompos sekam terhadap pertumbuhan dan hasil tanaman terung pada tanah PMK. (2) Dosis pemberian kompos sekam yang memberikan pengaruh pertumbuhan dan hasil terbaik tanaman terung pada tanah PMK. Variabel bebas penelitian ini adalah kompos sekam, tinggi tanaman, diameter batang, dan berat buah sebagai variabel terikat.

\section{METODOLOGI PENELITIAN}

Penelitian ini dilakukan dengan metode eksperimen lapangan dan menggunakan rancangan lingkungan dengan pola Rancangan Acak Kelompok
(RAK). Faktor perlakuan pada penelitian ini adalah kompos seka m padi yang terdiri dari sembil antara $\mathrm{f}$ perlakuan, yaitu: $\mathrm{k}_{0}=$ tidak diberi kompos sekam; $\mathrm{k}_{1}=0,5 \mathrm{~kg}$ kompos sekam per $\mathrm{m}^{2} ; \mathrm{k}_{2}=1$ $\mathrm{kg}$ kompos sekam per $\mathrm{m}^{2} ; \mathrm{k}_{3}=1,5 \mathrm{~kg}$ kompos sekam per $\mathrm{m}^{2} ; \mathrm{k}_{4}=2 \mathrm{~kg}$ kompos sekam per $\mathrm{m}^{2} ; \mathrm{k}_{5} \quad=2,5 \mathrm{~kg}$ kompos sekam per $\mathrm{m}^{2} ; \mathrm{k}_{6}=3 \mathrm{~kg}$ kompos sekam per $\mathrm{m}^{2} ; \mathrm{k}_{7}=3,5 \mathrm{~kg}$ kompossekam per $\mathrm{m}^{2} ; \mathrm{k}_{8} \quad=4 \mathrm{~kg}$ kompos sekam per $\mathrm{m}^{2}$. Jumlah tanaman yang diamati dalam penelitian ini adalah 108 tanaman. Data hasil pengamatan dianalisis dengan sidik ragam terlebih dahulu dilakukan uji normalitas dan homogenitas, kemudian dilanjutkan denganuji Beda Nyata Jujur (BNJ) padatarafnyata 0.05 dan 0.01 .

\section{HASIL DAN PEMBAHASAN}

\section{Hasil}

Hasil pengamatan terhadap peubah tinggi tanaman, diameter batang, dan berat buah per tanaman dianalisis dengan uji $\mathrm{F}$, seperti yang tertera dalam Tabel 1.

Hasil analisis ragam diketahui bahwa pemberian kompos sekam berpengaruh terhadap perubahan tinggi tanaman, diameter batang, dan berat buah. Hasil uji BNJ disaji dalam Tabel 2. 
Pengaruh Pemberian Kompos Sekam Terhadap Pertumbuhan dan Hasil Tanaman Terung (Solanum melongena, L.) Pada Tanah PMK

Tabel 1. Hasil analisis ragam peubah tinggi tanaman, diameter batang, dan berat buah per tanaman.

\begin{tabular}{|c|c|c|c|c|c|c|}
\hline \multicolumn{7}{|c|}{ Tinggi Tanaman } \\
\hline SK & DB & JK & KT & F hitung & $\mathbf{0 , 0 5}$ & $\mathbf{0 , 0 1}$ \\
\hline Kelompok & 2 & 14,02 & 7,01 & $1,27^{\mathrm{ns}}$ & 3,63 & 6,23 \\
\hline Perlakuan & 8 & 119,88 & 14,98 & $2,72^{*}$ & 2,59 & 3,89 \\
\hline Galat & 16 & 88,19 & 5,51 & & & \\
\hline Total & 26 & 222,09 & & $\mathbf{k k}=$ & 11,16 & \\
\hline \multicolumn{7}{|c|}{ Diameter Batang } \\
\hline Kelompok & 2 & 1,13 & 0,57 & $0,92^{\mathrm{ns}}$ & 3,63 & 6,23 \\
\hline Perlakuan & 8 & 17,71 & 2,21 & $3,60^{*}$ & 2,59 & 3,89 \\
\hline Galat & 16 & 9,84 & 0,62 & & & \\
\hline Total & 26 & 28,69 & & $\mathbf{k k}=$ & 9,15 & \\
\hline \multicolumn{7}{|c|}{ Berat Buah } \\
\hline Kelompok & 2 & 0,01 & 0,00 & $0,51^{\mathrm{ns}}$ & 3,63 & 6,23 \\
\hline Perlakuan & 8 & 0,44 & 0,06 & $8,30^{* *}$ & 2,59 & 3,89 \\
\hline Galat & 16 & 0,11 & 0,01 & & & \\
\hline Total & 26 & 0,56 & & $\mathbf{k k}=$ & 30,29 & \\
\hline
\end{tabular}

Sumber: data pengamatan, 2016.

Tabel 2.Hasil uji BNJ PengaruhPemberian kompossekamterhadap tinggi tanaman, diameter batang dan berat buah per tanaman.

\begin{tabular}{cccccc}
\hline \multicolumn{2}{c}{ Tinggi Tanaman $(\mathbf{c m})$} & \multicolumn{2}{c}{ Diameter Batang $(\mathbf{m m})$} & \multicolumn{2}{c}{ Berat Buah (kg) } \\
Perlakuan & Rerata & Perlakuan & Rerata & Perlakuan & Rerata \\
\hline $\mathrm{k}_{1}$ & $18,58 \mathrm{a}$ & $\mathrm{k}_{1}$ & $7,14 \mathrm{a}$ & $\mathrm{k}_{0}$ & $0,03 \mathrm{a}$ \\
$\mathrm{k}_{0}$ & $18,92 \mathrm{a}$ & $\mathrm{k}_{0}$ & $7,22 \mathrm{a}$ & $\mathrm{k}_{1}$ & $0,09 \mathrm{a}$ \\
$\mathrm{k}_{6}$ & $18,92 \mathrm{a}$ & $\mathrm{k}_{5}$ & $8,62 \mathrm{~b}$ & $\mathrm{k}_{2}$ & $0,23 \mathrm{~b}$ \\
$\mathrm{k}_{5}$ & $19,00 \mathrm{a}$ & $\mathrm{k}_{3}$ & $8,66 \mathrm{~b}$ & $\mathrm{k}_{3}$ & $0,25 \mathrm{~b}$ \\
$\mathrm{k}_{8}$ & $21,33 \mathrm{ab}$ & $\mathrm{k}_{7}$ & $8,70 \mathrm{~b}$ & $\mathrm{k}_{4}$ & $0,29 \mathrm{~b}$ \\
$\mathrm{k}_{2}$ & $22,33 \mathrm{ab}$ & $\mathrm{k}_{6}$ & $8,76 \mathrm{~b}$ & $\mathrm{k}_{6}$ & $0,33 \mathrm{bc}$ \\
$\mathrm{k}_{3}$ & $22,83 \mathrm{~b}$ & $\mathrm{k}_{2}$ & $9,05 \mathrm{~b}$ & $\mathrm{k}_{7}$ & $0,38 \mathrm{c}$ \\
$\mathrm{k}_{7}$ & $22,83 \mathrm{~b}$ & $\mathrm{k}_{8}$ & $9,49 \mathrm{~b}$ & $\mathrm{k}_{5}$ & $0,41 \mathrm{c}$ \\
$\mathrm{k}_{4}$ & $24,58 \mathrm{~b}$ & $\mathrm{k}_{4}$ & $9,52 \mathrm{~b}$ & $\mathrm{k}_{8}$ & $0,43 \mathrm{c}$ \\
\hline \multicolumn{2}{c}{ BNJ 0,05 $=\mathbf{3 , 8 3}$} & \multicolumn{2}{c}{ BNJ 0,05 = 1,28} & \multicolumn{2}{c}{ BNJ 0,05 = 0,13 } \\
BNJ 0,01 = 4,76 & \multicolumn{2}{c}{ BNJ 0,01 = 1,59 } & \multicolumn{2}{c}{ BNJ 0,01 = 0,17 } \\
\hline
\end{tabular}

Sumber : data pengamatanpenelitian, 2016

Angka yang disertaihuruf yang samamenujukkantidakbedanyatapadataraf 0,05

Hasil uji BNJ pada Tabel 2 kompossekam menghasilkan rata-rata diketahui bahwa pemberian $4 \mathrm{~kg}$ tinggi tanaman yang tidak lebih tinggi 
daritanaman yang diberi $1 \mathrm{~kg}, 1,5 \mathrm{~kg}, 3,5$

$\mathrm{kg}$, dan $2 \mathrm{~kg}$, demikian juga padahasil diameter batang. Pada pengamatan berat buah diketahui bahwa pemberian kompos sekam $3 \mathrm{~kg}$ tidak menghasilkan berat buah yang lebih tinggi dari tanaman yang diberi $4 \mathrm{~kg}, 2,5 \mathrm{~kg}$, dan 3,5 $\mathrm{kg}$.

\section{Pembahasan}

Hasil analisis data diketahui bahwa pemberian kompos sekam padi berpengaruh terhadap pertumbuhan danhasil tanaman terung padatanah PMK. Selanjutnya darihasiluji BNJ didapati pemberian kompos sekam padidalam dosis yang tertinggi tidakmemberikan perbedaan yang nyata pada pengamatan tinggi tanaman, diameter batang, danberat buah per tanaman dalamhal ini adalah pemberian $4 \mathrm{~kg}$ per $\mathrm{m}^{2}$.

Penyebab terjadinya tidak adabeda nyatapada tinggi tanaman, diameter batang, danberat buah per tanaman karena pemberian kompos yang banyak menurut Maslihat (2003:38), pemberian pupuk kandang yang banyak tidakakan meningkatkan pertumbuhan tanaman tetapi hanyaakan menambah bahan organik tanah danakan berpengaruh terhadap tanaman yang berumur panjang karena masih terus mengalami perombakan oleh mikroorganisme tanah sertasifa tfisik tanah menjadi lebihbaik.

Hasil uji BNJ terhadap tinggi tanaman, diameter batangdan beratbuah secar aumum lebihbaik pengaruhnya pada pemberian $2 \mathrm{~kg}$ per $\mathrm{m}^{2}$ atau 20 ton per hektar, halini disebakan oleh pemberian pupuk organik seperti kompos sekam menunjang pertumbuhan dan perkembangan tanaman karena hara yang tersedia di dalam bahan organic tersebut. Menurut Hess Dieter dalam Muslihhat (2003:38), pertumbuhan tinggi tanaman dipengaruhi oleh perpanjang sel, pertambahan diameter batang dipengaruhi oleh pembesaran sel, dan berat buah ditentukan oleh jumlah dan ukuran sel. Menurut Hardjadi (1907:46), percepatan pertambahan ukuransel dipengaruhi oleh peran Nitrogen. Apabila Nitrogen tersedia pada tingkatan yang berlebihan maupun kekurangan akan berdampak pada pertumbuhan dan perkembangan tanaman. Menurut Purnomo, dkk., (1993:27-35), pemberian pupuk organik termasuk kompos 20 ton per hektar menjadikan tanah dalam keadaan seimbang baikfisik, kimia, maupun biologi. 
Secara fisik pupuk organic kompos sekam padi membentuk agregat tanah yang mantap, sehingga berpengaruh terhadap porositas dan aerasi tanah dan menyebabkan perkembangan akar tanaman menjadi lebih baik. Secara kimia kompos sekam padi akan mengikat unsur hara yang bersifat racun bagi tanaman seperti $\mathrm{Al}$, $\mathrm{Fe}$, dan $\mathrm{Mn}$, serta menaikan $\mathrm{pH}$ tanah. Secara biologi pemberain kompos sekam padi akan memperkaya mikro organisme dalam tanah, sehingga mikro organisme dapat mempercepat ketersediaan hara bagi tanaman.

\section{KESIMPULAN DAN SARAN}

1. Pemberian kompos sekam berpengaruh terhadap pertumbuhan dan hasil tanaman terung pada tanah PMK.

2. Pemberian kompos sekam $2 \mathrm{~kg}$ per $\mathrm{m}^{2}$ pada tanah PMK menghasilkan berat buah tertinggi dengan berat rata-rata $0,33 \mathrm{~kg}$ atau 330 gram per tanaman. 


\section{DAFTAR PUSTAKA}

Aksi Agraris Kanisius. 2000. Dasar-Dasar Bercocok Tanam. Yogyakarta: Kanisius.

Balai Penelitian Tanaman Obat. 2000. Manfaat Terung. Jakarta: Balai Penelitian Tanaman Obat.

BPS Kabupaten Sintang. 2015. Kabupaten Sintang Dalam Angka. Sintang: BPS Kabupaten Sintang.

Buckman, H.O dan N.C. Brady, 1982. Ilmu Tanah. Diterjemahkan oleh Soegiman. Jakarta: Bharata Karya Aksara.

DEPTAN RI. 2010. Budidaya Terung. Jakarta: DEPTAN RI.

Hakim, N. Nyakpa, M.Y. Lubis, A.M., Nugroho, S.G. Saul. M.R., M.A., Hong, G.B., H.H. 1986. Dasar-Dasar Ilmu Tanah. Lampung: Universitas Lampung.

Hardjowigeno, S. 1992. Klasifikasi Tanah dan Pedogenesis. Jakarta: Akademika Pressindo.

LIPTAN DEPTAN. 2009. Pupuk Organik. Jakarta: Lembaga Penelitian Departemen Pertanian Republik Indonesia.

Musnamar, E.I. 2003. Pupuk Organik. Jakarta: Penebar Swadaya.

Nykpa, M.Y., Lubis, A.M., Pulung, M.A., Amrah, A.G., Munawar, A., Go Ban Hong, dan Hakim, N. 1998. Kesuburan Tanah, Lampung: Universitas Lampung.

Prasetyo, B.H., danSuriadikarta, D.A. 2006. Karakteristik, Potensi, dan Teknologi Pengelolaan Tanah Ultisol Untuk Pengembangan Pertanian Lahan Kering di Indonesia. Bogor: Jurnal Litbang Pertanian, Nomor: 25 edisi ke-2.

Rubaztky, dan M. Yamaguchi. 1998. Sayuran Dunia Ke III. Bandung: ITB Pers.

Rukmana, R. 2005. Budidaya Terung. Yogyakarta: Kanisius.

Samadi, B. 2001. Budidaya Terung Hibrida. Yogyakarta: Kanisius. 
Sastrosupadi, A. 2000. Rancangan Percobaan Praktis Bidang Pertanian. Yogyakarta: Kanisius.

Soetasad,A.A., Sri Muryanti dan H. Sunarjono. 2003. Budidaya terung lokal dan terung Jepang. Jakarta: Penebar swadaya.

Suhartono, B.H. 2007. Pupuk Kompos. Yogyakarta: Kanisius.

Wahyono, S., Sahwan., L. Firman., Suryanto., Freddy. 2003. Mengolah Sampah Menjadi Kompos. Jakarta: Pusat Pengkajian dan Penerapan Teknologi Lingkunga 